\title{
New Issues and Old: Women and Politics in Ireland, 1914-18
}

The First World War cast its shadow over Ireland just as it did over the rest of the United Kingdom. But Ireland's particularly combustible circumstances, coupled with the opportunity the war presented to Irish republican conspirators, meant that its influence over political, social and cultural life was more profound in Ireland than anywhere else in the British Isles. The War provided a vital context for the radicalisation of Irish society in the early twentieth century, fuelling forms of Irish martial culture which were already close to boiling point by August 1914. This was clearly the case for the Irish Volunteers and for the Ulster Volunteer Force, two armed militias which had been formed in response to the seeming inevitability of Irish Home Rule. But it was just as true for activist Irish women, many thousands of whom were already deeply involved in nationalist and unionist politics and who were, in common with their male counterparts, obliged to adapt to new political realties and expectations on the declaration of hostilities.

Although much less well-known and barely researched by Irish historians, feminist concerns, especially women's suffrage, were dynamic and important fixtures in the political culture of early twentieth century Ireland. Feminist activism and ideas touched all aspects of Irish political life in the period, from the national question, to socialism, to pacifism and to social reform activism. Many Irish feminists were, unsurprisingly, involved in a wide array of political and social campaigns and they too were affected by the militarisation and radicalism of Irish politics from 1912. Irish suffragettes had in fact contributed to this radicalisation in a vital way through their acts of militancy, many of which preceded the establishment of the male militias...

It was because so many Irish women were already deeply embedded in the political life of their country that they were well placed to adapt quickly and efficiently to the challenges initiated by Britain's declaration of war against Germany in the summer of 1914. The country's existing network of philanthropic and political organisations provided a firm foundation for a wide variety of voluntary war work and ongoing political activism, and they were quickly bolstered by a raft of new societies, established explicitly to coordinate Irish women's contribution to the allied war effort. The war acerbated some existing tensions between women's groups and reignited debates about militancy and pacifism in particular. But it also provided remarkable opportunities for Irish women. While some embraced the chance to do their bit in the national interest, others reaffirmed their opposition to any form of Irish involvement in British militarism.

As well as allowing for the expression of a wide range of political and social activism, Irish military involvement in the war forced some women's groups to clarify their positions and to move in new political directions. This was clearly the case for the nationalist Cumann na $\mathrm{mBan}$ which split over the question of Irish involvement in the war effort and moved in an increasingly conspiratorial and revolutionary direction. But the war galvanised even the most respectable and conservative women's groups and no organisation was untouched by it. Even those who disapproved of it could take advantage of the opportunities it offered. The war 
allowed organisations as politically removed as Cumann na mBan and the Church League for Women's Suffrage to expand and to take on new forms of training, and it helped to reduce the novelty of the 'lady politician'.

By 1918, Irish women had taken on new forms of employment, sat on more committees and coordinated more public works than ever before, as well as having done more than their share of fund-raising and voluntary work. Some had even participated in armed revolt, while others still had coordinated opposition to conscription, all the while keeping the women's suffrage flag flying. The Great War provided the essential context to all this activity, galvanising women's activism more than ever before and providing challenges as well as invaluable opportunities to a wide range of female activists. The war prompted a great deal of debate among women, but it also provided them with unrivalled opportunities to pursue existing causes and to harness them to new social and political concerns.

\section{I}

Irish women were involved in an enormous variety of political and social campaigns in the early twentieth-century. Membership was often shaped by ideological, regional and even confessional allegiances, no less so than in the women's suffrage movement. Ireland's women's suffrage movement on the eve of the First World War was diverse and dynamic. The country's largest cities, Dublin and Belfast, remained central to the movement as a whole, but regional societies also provided platforms for energetic activists. Some towns and cities produced stand-alone societies, while others hosted branches of Ireland's main suffrage societies, the Irish Women's Suffrage and Local Government Association (IWSLGA) and the Irish Women's Franchise League (IWFL). Branches of British organisations including the Church League for Women's Suffrage (CLWS), the Women's Social and political Union (WSPU) and the Women's Freedom League were also founded, though these tended to be less successful at attracting members than indigenous societies. Many other suffrage organisations emerged, leading to the establishment in 1911 of the Irishwomen's Suffrage Federation (ISF), a non-militant and non-party umbrella organisation which sought to coordinate suffrage activity across Ireland. It was to become a leading organizing body for Irish women's voluntary war work.

The methods espoused by the various suffrage groups inevitably differed, as did the political views of individual members. The national question impacted on the Irish suffrage movement, especially from around 1910 when a third Home Rule bill looked imminent, but fatal divisions between unionist and nationalist suffragists were neither inevitable nor recurrent. Most activists successfully put aside their nationalism or their unionism when they campaigned together as suffragists, most famously in 1912 when women from around the country staged a mass protest against their exclusion from the Home Rule Bill. ${ }^{1}$ The establishment in 1912 of the Irish Citizen, a feminist newspaper, reflected the level of interest in feminist politics. It survived until 1920, a remarkable achievement given the extent to which Irish political life was radicalised by war and insurrection from 1912; many other militant newspapers and periodicals were launched before failing or being forced to close 
over the same period. The journal hosted a number of sometimes frank debates between activists who held opposing views on a range of issues including militancy, socialism, nationalism, unionism and pacifism, but it nonetheless served as a genuine forum for the country's feminist activists.

The outbreak of War brought some existing tensions to the surface, as well as forcing feminists to take a public stand on the efficacy or otherwise of the conflict itself. Irish suffragists held varied opinions about the morality of war in general and about the Great War in particular. The Irish Women's Franchise League, Ireland's leading militant suffrage society, stood at one end of the spectrum. Its public stand on the war was unequivocal, declaring itself to be in 'no doubt whatsoever that the main current of the women's movements, in all countries, is decidedly hostile to war and aims at its abolition. We are consequently opposed to this war and to every war'. ${ }^{2}$ It believed that any concession to the 'war mongers' would only undermine the 'moral strength of the demand for women's emancipation'. ${ }^{3}$ Their form of opposition to the war included an absolute boycott of any kind of war-work, even relief work. This was certainly not a unique position among feminist organisations across Europe, but it placed the League firmly in the minority of suffrage societies on the Continent, Britain and in Ireland. Given that the Irish Citizen's editorial line reflected the IWFL's, the distance between the paper and suffrage groups around the country was bound to grow and relations already strained over militancy in particular, were likely to be tested still further. Margaret Connery of the IWFL urged the Citizen's readers to 'stand fast by their organisation' and to reject the pleas of war mongers, but privately some of her fellow travellers were less sure about the ability of suffragists to resist calls to 'do their bit'. 4 Acknowledging that women would be moved by the suffering of civilians in particular, the IWFL's Margaret Emerson reiterated her organisation's hard-line position in late 1914 when she told a meeting that that 'no woman should do Red Cross or relief work or help the Belgium Fund, however strong her inclination'. 5 This was a lot to ask of its members.

At the other extreme stood the Women's Social and Political Union. The WSPU had been involved in a concerted campaign of propaganda and suffrage militancy in Ireland since around 1912, targeting and wooing both nationalist and unionist MPs at various times and antagonising most indigenous suffragists in the process. As in the rest of the United Kingdom, its Irish-based activists suspended their campaign on the announcement of war and prepared to do their patriotic bit for the national effort. Two members proposed to the Irish Under Secretary, for example, that a National Patriotic Society be set up in Ireland and that Emmeline Pankhurst should be brought to Dublin to speak at a monster recruitment meeting. Suspicious of the WSPU's reputation in Ireland and wary of the society's claim that they were by 1914 'recognised to be helping the Government', Matthew Nathan declined their offer. $^{6}$

But Nathan was to work closely with many other feminists over the war years, thousands of whom did take up various forms of war work. Most feminists appeared to resign themselves to the idea that Irish participation in the war effort was a necessary evil and that women should be prepared to contribute in the interest of national security and humanitarianism. 
Some women's organisations were of course more openly patriotic than others and these threw themselves into every aspect of war work which was open to them. This was unsurprisingly more common within unionist organisations. The 4,500 members of the Dublin Women's Unionist Club, for example, subscribed more than $£ 600$ for a motor ambulance which was to be used at the front. ${ }^{7}$ The Club had declared a political truce at the beginning of the war, but after the Easter Rising its members organised a women's petition which urged the 'the Imperial parliament' to 'safeguard the liberties of the minority in the three Southern Provinces of Ireland'. ${ }^{8}$ This was not a suffrage organisation, but it was one of the very few existing women's political organisations which elected to suspend normal politics.

The general consensus among Irish suffragists was that war work of various kinds could be undertaken in tandem with suffrage work and that neither one nor the other should be avoided. Very few took the extreme positions held by the WSPU or the IWFL. The ISF called an emergency executive meeting in August 1914 at which it decided that suffragists should include, among their other duties, 'the prevention and relief of distress during the present crisis'. Each federated society was asked to ratify this and having duly done so, the Federation as a whole decided to take an active part in the Suffrage Emergency Council (SEC), a body established to coordinate feminist responses to the war; all Irish suffrage groups apart from the IWFL joined.

Controversy rose at the August meeting of the ISF because of the suggestion that active suffrage work be abandoned in favour of relief work, ${ }^{9}$ but the Suffrage Federation insisted in the end that its own activities during the war proved that suffrage work could be maintained in the current extraordinary circumstances. The IWFL continued to maintain that feminists should dedicate themselves to suffrage first, and not be distracted by wartime jingoism. It even suggested that feminists should demand concessions from the government in exchange for their cooperation. The Suffrage Emergency Council, however, refused to accede to the suggestion that it should hold back its support for the war effort until it received a pledge from the government that suffrage would be granted at the end of hostilities. ${ }^{10}$ An earlier exchange between Hanna Sheehy Skeffington of the IWFL and Cumann na mBan had been similarly fraught. The response to Sheehy Skeffington's suggestion that Cumann na mBan reserve its support for the Irish Volunteers unless the male group pledged support for women's suffrage was swift and vigorous. Maire Ni Chillin described as 'a gratuitous insult to the women of Ireland ... the amazing suggestion that in return for our help we make a bargain with our men'. ${ }^{11}$

The SEC's assertion about women's responsibility to the fate of the nation was not uncommon, especially in the early days and weeks of the war when panic swept the country and accounts of German war atrocities were widely publicised. Even the pacifist Louie Bennett argued in late 1914 that suffrage societies should be willing and able to combine their relief work with their suffrage propaganda. ${ }^{12}$ She subsequently argued at an IWFL meeting that women had some responsibility for the war and that the Franchise League's refusal to participate in the war effort was short sighted.. ${ }^{13}$ Bennett was the most astute critic 
of the IWFL's alleged neutrality and of its pacifist claims. She objected to the Franchise League's brand of pacifism which made 'exceptions and reservations' and would have preferred a 'frank outburst of hatred' for England to the 'sly digs' made by IWFL members. ${ }^{14}$ She made her most succinct case when she asked Francis Sheehy Skeffington 'by what train of reasoning militant suffragists arrive at the state of becoming peace advocates? ${ }^{15}$

Opposition to the Citizen's stand on the war emanated from a number of other quarters. Many suffragists, like Elizabeth Browning, IWFL and IRL member, agreed that the suffrage flag had to be kept flying during the war, but claimed that the paper's policy of 'suffrage first and suffrage only' had taken the publication so far off course that she might well have to distance herself from it. ${ }^{16}$ She resigned from the IWFL two months later. ${ }^{17}$ The Irishwomen's Reform League disassociated itself from the Citizen for a period of three months, refusing to sell the paper or to submit its reports to it for publication. This was done in protest not against the paper's declaration of neutrality, but because of its alleged violation of that stand as seen in the 'anti-recruiting tone' of some of its articles and in the poster, which read 'Votes for Women Now! Damn Your War!, issued by the Citizen. ${ }^{18}$ After three months Helena Chenevix reported that the IRL would resume its relationship with the Citizen, but its editor, the militant anti-war activist, Francis Sheehy Skeffington, mocked Chenevix in private telling a friend that the IRL 'suffered more than the paper from their temporary defection'. ${ }^{19}$

Dora Mellone, Secretary of the Warrenpoint and Rostrevor Suffrage Society and of the Irishwomen's Suffrage Federation, became the very active secretary of the SEC, and another outspoken critic of the Citizen's stand on suffragist war work. By the end of 1915 she was telling Francis Sheehy Skeffington that members of her Suffrage Federation throughout the country were 'displeased' with the paper, despite its having 'given up those charges of treachery to the woman movement \&c., to which I and others object' and which had featured in the early months of the war. ${ }^{20}$ Though clearly patriotic, Mellone could hardly be described as mindlessly jingoistic. She insisted very strongly that militarism should not be permitted to 'swamp' the Irish suffrage movement which must be kept alive during the war, and that the Suffrage Emergency Council was good for the women's movement overall as it allowed suffrage societies to sustain their identity rather than becoming subsumed into the general mass of war workers. ${ }^{21}$ In acknowledging that opinions on the war varied among Irish feminists, she also reminded the IWFL that unity within the suffrage movement was only possible if suffragist activists kept personal opinions about controversial issues including the national question and the efficacy of the war, to themselves. ${ }^{22}$ Like Bennett, she had little faith in the IWFL or the Irish Citizen's claims to neutrality.

There is little doubt that suffrage societies and suffragists themselves did, as Mellone and others argued they should, maintain a high profile during the war years, and many combined feminist and relief work, often in the expectation that this would bode well for the cause of women's suffrage in peacetime. The IWSLGA insisted that the war had increased the likelihood of the granting of the parliamentary franchise, declaring in 1917 that the 'march of events had become a triumphal procession towards our long desired goal'. Its committee 
carried a resolution which claimed that the right of women to full citizenship was now more justified than ever before. ${ }^{23}$ Lady Wright, president of the Irishwomen's Suffrage Association agreed, arguing that the war had allowed women to 'display their organising powers. ${ }^{24}$ Edith Somerville of the Munster Women's Franchise League looked to the position of women in post war Ireland as early as 1915 when she and Violet Martin began to compile a record of the 'magnificent' work done by suffragists. This, she argued, would in the future 'form an argument in our favour hardly to be gainsaid'. ${ }^{25}$ As early as 1914, the Church League for Women's Suffrage was predicting that if women failed to be enfranchised during the 'general rearrangement of affairs at the close of the war', they might be without it for many years hence. ${ }^{26}$ Edith Londonderry even accepted a bet in 1915, that women would have won their case by the end of the war. They had, she insisted, only ever wanted 'the opportunity to prove themselves'. 27

The prospect of enfranchisement even seemed to revive some feminist societies, some of which, like the Sligo Suffrage Society, had appeared to be in abeyance for some time. ${ }^{28}$ The Church League for Women's Suffrage argued that its war work had won it a great deal of support, and even that its membership had 'steadily increased' despite the outbreak of war. ${ }^{29}$ The foundation of the Irish Catholic Women's Suffrage Association (ICWSA) in 1915 similarly suggested that the movement's appeal survived throughout the war years. Loosely allied to the larger British Catholic society, news of the Irish branch's activities appeared occasionally in the Catholic Suffragist, but it very much operated independently of London. Spearheaded by Mary Hayden and Mary Gwynn, it quickly attracted a number of constitutional nationalists and evolved into the closest openly nationalist suffrage organisation Ireland hosted in these years.

Although Gwynn and Hayden maintained a perfectly cordial relationship with the militants of the Irish Women's Suffrage League, the society began to distance itself from the Citizen, just as many other suffrage organisations had. The paper was read at ICWSA meetings, but the Catholic league stopped sending reports to the Citizen because 'feeling about the war' ran so high and some members would 'very likely fasten on something of that kind and make a fuss.${ }^{30}$ Many members of the ICWSA were involved in various types of voluntary war work or had relations who joined the British Army: Mary Gwynn's MP husband was, for instance, one of the Irish Party's busiest recruiters.

One could argue of course that suffrage societies were bound to insist on the endurance of the suffrage demand, and to claim concessions in the light of their wartime work, but wider public opinion about women's roles also appeared to shift during the war years. The Lady of the House, a fashionable women's journal, lauded women's war work from 1915. Its 'Women's Parliament' section hosted debates about women's post-war prospects, dress reform and the future of the 'blue stocking'. The verdict amongst its readers appeared to be unanimous. Maud White of Holywood stated that 'in respect of women's employment, the European war is admittedly a war of liberation'. ${ }^{31}$ On a more practical level, Mrs Hanrahan from Cork declared that the women who had during the war years experienced the "convenience and comfort of a workmanlike working "outfit"' would not readily "swathe 
their poor limbs in yards and yards of useless stuff, nor yet hamper them with sheath skirts a yard and a quarter in circumference as was the case a few years ago'. ${ }^{32}$ Liberation evidently came in many forms.

The social good of Irish society and particularly of Irish women and children remained a pressing issue for Irish feminists and social activists over this period and the war in fact provided many of them with new opportunities to pursue some of their favoured causes, as well as tackling new social problems and those many believed would be exacerbated by war. Despite its opposition to the war, even the IWFL took advantage of some of the opportunities it allowed, supporting initiatives which aimed to improve or protect Irish women, especially those whose lives had been disadvantaged or dislocated on the outbreak of war. This did not constitute war work as such, but the line between objectionable war-work and acceptable relief work could be very fine indeed. An emergency meeting of the Church League for Women's Suffrage, for instance, established a 'Suffrage Union for Social Service' which set up a workshop for women and girls who had lost employment because of the war. They came to employ more than one hundred women and among the items they produced were army shirts stamped with 'Suffrage War Relief Workroom'. ${ }^{33}$ Did this workshop support women or support militarism? This was one of the many instances during the war years when feminists and pacifists were faced with this dilemma. The Citizen's tone overall towards most such schemes remained belligerent and this clearly continued to cause real anxiety among some of its readers and even among the IWFL's own members. Violet Crichton, for instance, a member of the Executive Committee of the Irishwomen's Suffrage Federation, agreed with her friend Hanna Sheehy Skeffington that suffrage work had to go on during the war, but she explained that she disliked "the scornful way those who give up all their time to "war-work" are talked about'. ${ }^{34}$

Both Crichton and Dora Mellone also insisted that women's involvement in war work should not come at the expense of the rights of working women. In her position as SEC Secretary, Mellone was both a very active voluntary war work coordinator and a guardian of women's employment rights. She complained, for instance, that women workers in Belfast were being exploited by factories which took on voluntary workers. She also drew attention to the fact that Ireland's two women factory inspectors had been removed to London and Scotland during the war. ${ }^{35}$ The Irishwomen's Reform League kept up its campaign for equal pay and better conditions for women workers and in early 1915 it reversed its decision to prioritise relief work over suffrage work. In was involved in the same year in a conference on the position of women in industry in Ireland, during which many women's groups reflected on the 'growing feeling of the need of bringing together at the present time those who are interested in social and industrial questions, especially on account of the many new problems caused by the war'. ${ }^{36}$ This was only one of the many organisations established by and for women during the war which aimed to tackle the many social and economic problems thrown up or accelerated by the crisis. By the end of 1915 a number of women joined together to found the Irishwomen's Association which aimed to act as a centre of information on all 
questions affecting women and children. It was in some ways a wartime version of the Irishwomen's Suffrage Federation in so far as it was a coordinating body only, but it did not appear to last as long. ${ }^{37}$

The outbreak of war presented reformist and feminist women with new opportunities to pursue some existing causes as well. A Joint Committee of delegates from various Irish women's societies, some of them feminist, some philanthropic, all of them broadly reformist in their emphasis on improving the lives of women and children, was formed to coordinate relief and social work. ${ }^{38}$ This committee continued to press for the enfranchisement after the war of women on the same terms as men, supported the election of more women as poor law guardians and it had two women appointed to the Dublin War Savings Committee. ${ }^{39}$ At the same time, members become involved in a number of new forms of social work including a voluntary women's patrol, monitoring public houses for breaches of licensing laws and organising chaperones for the many women who found themselves travelling alone over the war years. ${ }^{40}$

Other women's groups took advantage of wartime economic conditions when seeking new forms employment for women. New women's workrooms produced a good many items which had traditionally been imported from Germany (especially toys), and others were trained to replace German workers such as waiters. ${ }^{41}$ Their experiences reflected wider retrenchment in non-essential industries which were hit hard by the collapse in demand for goods including expensive clothing and textiles and fine furniture. ${ }^{42}$ Some societies looked beyond the war when organising positions for women. Maud Walsh of the Women's Section of the Department of National Service in Ireland, for example, argued that the women's war work would reach 'only the initial stage' by the end of the war, and would pave the way for female involvement in post-war industrial development. ${ }^{43}$

Feminist organisations were therefore concerned both with coordinating their own voluntary war work, and ensuring that working women in particular were not disadvantaged through lack of employment or support during the war. The Irish Central Bureau for the Training and Employment of Women had been in existence since 1903 when it was launched to collect information on women's work, to assist women who wished to take up paid work, to put employers in touch with trained workers and to coordinate the efforts of the many organisations which existed to aid women seeking employment. ${ }^{44}$ The Bureau had considered closing down for the duration of the war in 1915, but it survived, becoming a kind of 'clearing house' for all matters relating to women's employment. It found that not only was it inundated by enquires from women who wanted 'to do war work', it was also compelled to deal with numerous 'war cases', many of an 'urgent nature', where women had lost their jobs. $^{45}$

Most campaigners appeared to be especially concerned about the employment rights and prospects of working-class women. Helen Chenevix even urged women of 'leisure and independence' to avoid taking up posts which were desperately needed by women who had lost their own jobs and were absolutely dependent on their earnings. ${ }^{46}$ Not content merely to 
refuse to participate herself in the war effort, Hanna Sheehy Skeffington even suggested that the women who rushed into voluntary war work, especially nursing, could under-cut the women whose livelihoods would as a consequence be threatened. ${ }^{47}$ But middle-class jobs were at risk too, so much so that Elizabeth Browning approached Matthew Nathan about establishing an Irish sub-committee which would deal especially with cases of professional women who had lost their work during the war. ${ }^{48}$ Nathan thought this unnecessary as an Irish Central Committee for the Employment of Women (ICCEW) already existed. Two ICCEW committees were launched, one which covered Munster, Connaught and Leinster and another which covered the nine counties of Ulster. ${ }^{49}$

Both committees attracted women already active in suffrage and other politics. The ICCEW was not in reality equipped to deal with professional employment and such cases probably fell through the cracks. They instead became concerned with securing work and training for women in manual occupations including domestic service and textiles and they managed to secure several lucrative government contracts for the production of items such as shirts, hosiery and underwear. ${ }^{50}$ The two main organising bodies oversaw smaller Local Representative Relief Committees (LRRC) which were established in counties, boroughs and districts which had populations of more than 5,000, and which were charged with finding or organising suitable work for women. ${ }^{51}$ Eligible women were deemed to have been thrown into economic distress by the war and not by general economic conditions. The Ulster organisers appeared to have been much more efficient as they founded many more local committees than their southern and western counterparts. ${ }^{52}$ This may have been because more opportunities for suitable employment were available in the industrialised north, or it may have simply signalled the enthusiasm and skill of the northern committees. It almost certainly reflected the fact that employment opportunities and economic conditions varied enormously across the country. The Cork organisers explained that there was 'very little distress in Cork owing to the War', ${ }^{53}$ while one Dublin relief committee claimed that some of the women who came to their rooms looking for work 'actually fainted for want of food'. ${ }^{54}$

Such comments reflected the extent to which Irish economic conditions varied widely over the war years. On the one hand, Ireland's farmers did well out of the war, and 'agricultural production flourished to a degree unknown since the Napoleonic wars'. ${ }^{55}$ At the same time, employment patterns and opportunities for Irish women were not as greatly altered as they were in other parts of the British Isles. ${ }^{56}$ The absence of conscription, the almost complete halt to emigration to America from the first half of 1915, and the high rate of unemployment before the war meant that gaps left by enlisting men could easily be filled by other men rather than by unemployed women. ${ }^{57}$ The country's structural difficulties were reflected in the fact that while unemployment was virtually eliminated in Britain, it was merely reduced in Ireland over the course of the war years, while both unemployment in towns and under-employment in rural areas remained entrenched. ${ }^{58}$ Nonetheless, life undoubtedly improved for many workers as new job opportunities became available for many of them and poverty overall appeared to decline, at least according to official figures. ${ }^{59}$ 
Yet, while Irish people were never issued with ration books, rising prices and shortages did cause hardship, especially among the poorest. Impoverished Dubliners in particular appeared to be hard hit at times. Bread prices in Dublin, for example, increased from $6.5 \mathrm{~d}$ per $4 \mathrm{lb}$ in 1914 to around 12d in 1917, a significant rise, albeit in line with the rest of the United Kingdom. ${ }^{60}$ British Trade union organisers claimed that the cost of food more generally, excluding meat, was more expensive in Ireland's five largest towns than it was in London. ${ }^{61}$ Dublin was particularly vulnerable to economic distress because of the curtailment of key industries including distilling and brewing and the number of people, especially women, who received relief, remained highest there. Their plight was not helped by the Easter Rising which brought many businesses and trades to a standstill. Dublin's Local Representative Committee was 'heavily taxed by numerous applications, mostly young girls, who had lost their employment through business houses in the City, and from the dependents of persons who had been accidentally killed or seriously wounded during the disturbances'. ${ }^{62}$

The politics of food distribution and availability became a feature of war-time debate. The necessity of the involvement of women in any decisions about food was recognised by almost all women's societies, especially after the introduction of legislation which ensured that at least one woman sat on every such committee in England. The Joint Committee of Irish Suffrage Societies demanded that this legislation be extended to Ireland and insisted that a woman should also be co-opted onto the all-male Central Committee, ${ }^{63}$ while the Irish Women Workers Union demanded the involvement of working-class women in all such bodies. ${ }^{64}$ In 1917, the Local Government Board agreed to support the establishment of communal kitchens in Dublin and to increase the amount available for meals for children in recognition of the high cost of living. ${ }^{65}$ Republican women including Helena Molony and Maire Perolz joined with Louie Bennett, Jennie Wyse Power, Alice Barry and a number of others, some of them establishment figures, to undertake the management of the kitchens which supplied cooked food at or close to cost price. ${ }^{66}$ Self-help also flourished with the vast expansion of allotments throughout the country, giving an enormous boost to Cecilia Harrison's Vacant Land Cultivation Society which had more than sixty acres under cultivation by the end of $1917 .^{67}$

Even those political women who were implacably opposed to the war, benefited from the opportunities it offered their organisations. Like the Irish Women's Franchise League, Cumann na mBan was opposed to Irish involvement in the war effort. Unlike leading supporters of the IWFL, however, its members were not pacifists. On its foundation in early 1914, Cumann na mBan had been open to and indeed, had attracted a number of high profile constitutional nationalist women to its ranks, as well as women well known in Sinn Fein and republican circles. Its first president, Agnes O'Farrelly, was in fact a staunch supporter of the Irish Parliamentary Party, as well as a leading opponent of the politicisation of the Gaelic League. Yet the organisation was from the outset developed around a strongly republican spine. Reconciling both wings became increasingly difficult and impossible after John 
Redmond declared Irish support for the allied war effort. After a painful and ultimately futile attempt by O'Farrelly to keep the organisation untied, it split in December, 1914. The Redmondite members who had hung in until the end then drifted off, most probably into war work in the majority of cases. The remaining radicals threw themselves into republican fund raising and anti-enlistment campaigning as well as preparations for an eventual showdown with the British state in Ireland.

In many ways, Cumann na $\mathrm{mBan}$ had a very good war as the growing militarisation of Irish society provided it with a valuable context in which to organise and propagandise. In 1914, Mary Colum, Cumann na mBan secretary, argued that 'the men at headquarters have too many other things at present to give their attention to. We are running the food question because it is usually the business of the women ... ${ }^{68}$ Her organisation explicitly politicized the issue by arguing from the early days of the war that Ireland's food must be 'conserved for the people of Ireland' in order to prevent a repetition of the 'horrors of the Black Famine of '47'. ${ }^{69}$ Individual members became involved in food procurement and distribution schemes, in many cases building on experience gained during the 1913 Lock Out. They were supported in this by members of the Irish Women Workers' Union, another organisation which took advantage of wartime conditions to expand. Union officials urged women workers to benefit from the new opportunities offered by the war. Their membership grew by about 2,000 by 1917, giving them some industrial clout. ${ }^{70}$ While opposing the war absolutely and denouncing the propaganda which sent Irish men to the trenches in order to allegedly protect the honour of their country women, they urged women to organise, to demand war bonuses and the parliamentary vote and to 'give the employers even more trouble than do the men'. 'As', they argued, 'the employers are so fond of conscription and compulsion, let them have it. Rub it in. Choke them with it. Compel them to pay decent wages'. ${ }^{71}$

Opposition to the war notwithstanding, members of both the Irish Citizen Army, an explicitly socialist and republican organisation, and Cumann an mBan made particularly good use of new opportunities available to women in nursing and first aid training. In this, they were one step behind their Unionist counterparts who had established Red Cross classes before the Great War began. Preparing themselves for the imposition of Home Rule, the Ulster Women's Unionist Council (UWUC) set about forming a network of voluntary aid units throughout Ulster from late 1913. ${ }^{72}$ By April 1914, it announced that it had 450 trained nurses and 3500 Voluntary Aid Detachments (VADs) ready to be mobilised when required. ${ }^{73}$ Before war was even declared, the Ulster VADs already had a membership of 3,520, more in total than the other three Irish counties combined by the end of the ar. $^{74}$

More extensive provision of first aid training was launched soon after war was declared. Red Cross classes in Dublin began towards the end of August, 1914, when the Women's National Health Association began to organise sessions for women only. Courses were also developed under the auspices of the Department of Agricultural and Technical Instruction (DATI), which drew up a syllabus of instruction and prepared to train and examine students in First 
Aid and Sick Nursing. DATI certificates were recognised by the War Office, the Red Cross and the St John's Ambulance Association, allowing successful graduates the widest possible scope for joining one of the many organisations which valued their skills. By the end of July, 1915, the Department had enrolled more than 10,000 students in first aid, nursing and ambulance classes in 179 centres across the country. ${ }^{75}$

Because of its inherent usefulness as a wartime skill, even those women who were opposed to the allied war effort were eager to take advantage of the opportunity to train as nurses and first aiders. Lady Aberdeen reported that some individual members of Cumann na mBan attended the August 1914 meeting which launched her Red Cross work in Ireland, along with representatives of the Women's National Health Association, the Irish Volunteers Aid Association and the St John's Ambulance Association. ${ }^{76}$ Cumann na mBan even considered seeking formal affiliation with the International Red Cross, but having been told by the Geneva authorities that it would have to apply for affiliation with the English Red Cross as Ireland did not have a standing army of its own, it declined. ${ }^{77}$ Jennie Wyse Power, active in Cumann na mBan from the outset, later recalled that that 'we decided to have nothing to do with the official Red Cross work with a reservation that, whenever the Red Cross was needed we would use it without permission from anyone'. ${ }^{78}$ Thus, Cumann na mBan shunned the organisations which coordinated nurses for the war effort, while continuing to take advantage of state-sponsored facilities for training them. Its members were often trained by fellow adherents or qualified Volunteers, before taking examinations provided by the DATI. ${ }^{79}$ It appears that British officials were generally unconcerned by the first aid training and recruitment work undertaken by advanced nationalist women, though Matthew Nathan was clearly aware of their activities and understood them to be direct imitations of militant unionist organisation in the north of the country. ${ }^{80}$ Given the enormous scale of the mobilisation of volunteer women and the apparent suspension of radical unionist activity from August 1914, it is likely that Nathan and his colleagues simply lost sight of the irritating but small scale efforts of Cumann na mBan and their Citizen Army comrades.

The fact that Cumann na mBan had not on its foundation been an explicitly republican organisation allowed for the profusion of an increasingly bewildering array of women's groups and initiatives in association with or in support of the Volunteers. ${ }^{81}$ Constitutional nationalists including Bridget Dudley Edwards, for example, had attempted to form an ambulance corps for the Volunteers, and plans were made for first aid and ambulance classes to be taught in branches. ${ }^{82}$ After the split in the organisation, many new women's groups which aimed explicitly to aid the Volunteers and the Irish war effort were proposed and formed around the country. ${ }^{83}$ They mirrored the many efforts which had been launched by unionist women in support of the war effort. Both unionist and nationalist women threw themselves into war work, presenting an almost unparalleled state of unity and common purpose. Although there is no doubt that these women did put aside, to some degree, the very deep political disagreements which had divided them before war was declared, it was also the case that tribal loyalties persisted over the war years, even in the face of a new, allegedly unifying common enemy. Nationalists and unionists had been preparing for a show-down since 1912, possibly even civil war. Cumann na mBan and the Ulster Women's Unionist 
Council were no less representative of this than their male equivalents. The fundamental political differences which had divided nationalist and unionist women might have been suspended in August, 1914, but they did not disappear and in fact characterised some aspects of war work.

In nursing, for example, the British Red Cross and the Irish section of the St John's Ambulance Association together coordinated the civilian voluntary effort for Munster, Connacht and Leinster, while the Ulster committee elected to operate separately, taking its instructions from Belfast's Red Cross Branch. ${ }^{84}$ Such demarcation was replicated in other war-related establishments including the War Hospital Supply organisation, a sphagnum moss receiving and distributing depot, A Prisoners of War Relief Committee and a Sailors' Help Society, each of which had 'a separate and independent replica in Ulster' ${ }^{85}$ It seemed that partition was a well-established fact of war relief.

Irish women's voluntary war work effectively had three major bases: Dublin, Belfast and London. The London work was mainly coordinated through the Irish Women's Association (IWA), formed in 1915 to provide comforts, food and clothing to the Irish regiments. Its list of patronesses included an impressive number of titled women as well as some more obviously political names. ${ }^{86}$ Although the Irish Women's Organisation declared itself absolutely non-party and non-political, some unionists clearly disagreed. Arguing that the IWA was 'nothing but an Irish Nationalist Organisation', the rival Ulster Women's Gift Fund accused its president, Lady MacDonnell, of 'doing her best to make the English people believe that the only organisation who looks after prisoners of war is the Irish Association formed by her'. The Fund also claimed that MacDonnell was attempting to 'cast a reflection upon the Ulster people', suggesting that that they had ignored their own. ${ }^{87}$

The Ulster Gift Fund was based in Belfast but worked through and with a London-based committee headed by Ladies Carson and Richardson. The organisation resented what it saw as the attempt of the Irish Women's Association to represent all Ireland, and was adamant that the Ulster regiments must be left to the Ulster women's organisation, lest the soldiers feel that they had been forgotten at home. This meant in practice that the Ulster organisation would pack and dispatch parcels to the three Ulster regiments only, while its rival could take care of the other Irish regiments. ${ }^{88}$ The division of labour involved in supplying comforts and necessities to Irish prisoners of war was complex and this made 'claiming' certain battalions and regiments difficult and, often, inherently political. By 1917, some compromise appeared to have been reached but the competition between the two women's committees replicated what appeared at times to be a wider rivalry between the Ulster war committees and the Southern Irish wartime coordinating bodies.

The tensions between nationalist and unionist women were never clearer than during the conscription crisis. The campaign to prevent the introduction of conscription to Ireland produced an unprecedented and never to be repeated level of cooperation between Irish women from across the nationalist, socialist and pacifist spectrums. It was launched in opposition to the specific threat of legislative coercion in 1918, but it was built upon years of 
anti-recruitment and anti-war activism. Irish suffragists were among the most dogged of all those who opposed the war and attempts to recruit Irish men into the British army. Margaret Connery and Francis and Hanna Sheehy Skeffington of the IWFL were early and dedicated anti-recruiters; in late 1914, for example, they were removed by police from one stormy antirecruitment march 'for their own protection'. 89

Such dedication was rare both within suffrage circles and within Ireland more generally, especially in the early months of the war when confidence that the conflict would be brief was high. It also drew such dissenting suffragists further into labour and advanced nationalist circles where they campaigned alongside like-minded radicals including James Connolly and Arthur Griffith. These protestors built on both an international pacifist movement and on a tradition of anti-recruitment which had become a particularly important aspect of Irish nationalism during the Boer War when republicans and even some constitutional nationalists had become involved in disrupting recruitment meetings and attempting to dissuade young Irish men from enlisting in the British Army. This practice was kept up after the end of the Boer War, mainly through the work of Inghinidhe na hÉireann whose activists adopted a variety of tactics including interrupting recruiters, leafleting the men they believed to be most at risk of joining the British Army and attempting to display their literature in the most unlikely of places. They managed, for example, to plaster Lord Aberdeen's car with antirecruitment placards while it was parked outside a Dublin shop. His chauffeur then drove the festooned car around town. ${ }^{90}$ They also attempted to apply moral pressure to women by trying to stop 'young Irish girls associating with British soldiers'. This often meant campaigning in some of Dublin's most notorious and squalid streets and it could be dangerous work. Inghinidhe na hÉireann and Cumann na mBan maintained this activity during the war years, joining at times with suffragists and organisations including the Socialist Party of Ireland, Sinn Fein, Fianna Éireann and the Irish Neutrality League. Many thousands of supporters joined them from early 1918 when conscription looked to be a real possibility.

Opposition to the conscription of Irish men was not universal however. The unionist leader, Edward Carson, advocated the extension of compulsion to Ireland as a way of equalising the alleged uneven sacrifice of Ulster and the rest of the country. ${ }^{91}$ His position more accurately reflected the views of Irish unionism, especially in Ulster. Many unionists and even some nationalists continued to support conscription until the end of the war. Some unionists met the announcement of the extension of the military Services Act to Ireland with approval, describing it as 'what the necessities of the hour and the good name of Ireland demand'. ${ }^{2}$ The news that Irish men would no longer be permitted to 'shelter behind the bodies of the more patriotic portion of the population' was thus greeted in unionist Ulster with relief as much as endorsement. ${ }^{93}$ This is not to say that such sentiment was unknown outside Ulster, even by 1918: Edith Starkie recalled her Catholic father's 'deep' sorrow when Ireland 'refused' conscription in 1916; He 'never', she wrote, doubted the rightness of the Allied cause'. ${ }^{94}$ Certainly there exited, as early as 1916, a pro-conscription lobby in the south of Ireland, evidenced by, for example, the letters written to the Irish Times regretting Ireland's exclusion from the first Bill. ${ }^{95}$ Many southern unionists and even some nationalists supported 
conscription in 1918, but the voice of the minority which held such opinions was overwhelmed by the sheer weight of Catholic opinion.

Irish women protested against conscription in a variety of ways, including their participation in a very well observed general strike in April. On the day of the strike, the IWFL hung a banner from its window which read 'CONSCRIPTION - No woman must take a man's job'. ${ }^{96}$ But the greatest expression of women's opposition to conscription was seen in June 1918, when they organised and participated in nationalist Ireland's largest ever women's protest. The impetus for Women's Day, or Lá na mBan, seemed to have grown out of a Dublin meeting called by the Irishwomen's Reform League which attracted many wellknown activist women including Alice Stopford Green, Susan Mitchell and Margaret Connery of the IWFL. ${ }^{97}$ Promoted as an occasion of mass resistance to conscription, this event was marketed as inclusive but it exposed some of the tensions which existed within women's political circles. ${ }^{98}$ The 'Woman's Day Committee' which was formed to coordinate the event included the pacifist Louie Bennett and the constitutional nationalists Agnes O'Farrelly, Helen Laird and Alice Stopford Green. They were supported by the Irish Women's Franchise League, Cumann na mBan, the Irish Women's Workers Union, and the International League among others. ${ }^{99}$ Thousands of women across the country marched, prayed and sign the anti-conscription pledge. In total, more than 40,000 women signed the pledge in Dublin alone. ${ }^{100}$ Woman's Day signified that women's protest had become a fact of Irish political life by 1918.

\section{IV}

For some Irish women was one of liberation and opportunity for their sex. Though few women took on new roles primarily in order to win political concessions, they nonetheless found themselves in a profoundly changed world by 1918, a world in which they would become political citizens. In a few short years many thousands of Irish women had become involved in a staggering array of voluntary and paid work while remaining committed to existing causes including women's suffrage. The disagreements which characterised the women's movement before the war persisted and were, at times, amplified. But they did not, on whole, divide the movement permanently. In fact, while activist women took up polarised positions on the allied war effort at times, they could and did join together to campaign on issues which affected women and children. Social activism around women's employment, alcohol, violence against women and the sexual, double standard increased during the war, acting as a kind of glue between individuals and organisations which often otherwise held disparate views.

Although many Irish women had been well versed in public speaking and activism before the war, changed social and political circumstances meant that many more took on new public roles. The Countess of Fingall recalled that 'we women had to take on our shoulders a great deal of the public work that men had done previously, taking the Chair at Committees, addressing meetings and so on'. In common with her fellow suffragists, she organised classes to train women in the skills they would need, in public speaking, chairing and delegation. ${ }^{101}$ 
There was no direct link between women's war work and their enfranchisement in 1918, but there was a correlation between what was expected of them by the state and their own sense of themselves as citizens. Additionally, the fact that Ireland was the most politicized part of the United Kingdom over the war years and that it experienced rebellion and revolution alongside the demands of total war, produced a society in political and social flux and one in which gender roles could be highly fluid. This can be seen as much in the involvement of republican women in the Easter Rising as it can in the involvement of unionist women in arming the Ulster Volunteer Force.

As well as learning new skills, Irish women had passed through periods of unthinkable grief and terror as their relatives were killed while their country inched closer to anarchy or revolution. Their lives and their status had been transformed by profound social changes which had arisen from the experience of total war. While military battles took place abroad, the home front itself became a battle zone where women tried to 'win' the war through their thrift, their voluntary and professional efforts and their ability to maintain domestic and social life while their sons and husbands were away. Society was itself profoundly feminised through the ascendency of issues relating to food, health, social reform, well-being and relief of distress, therefore elevating 'women's issues' to unprecedented levels of national importance. Women also looked increasingly capable of maintaining the functions of the state through their work on numerous food, employment, relief and enlistment committees. The argument that women could not be entrusted with governance at the highest level looked ever more feeble in the face of this unparalleled demonstration of administrative and bureaucratic competence. ${ }^{102}$ It is hardly surprising that a columnist for the Lady of the House should reflect in 1918 about the 'strange happenings' brought about the war, and remake on the fact that 'Parliamentary antagonism' towards women's suffrage had utterly collapsed. ${ }^{103}$

\footnotetext{
${ }^{1}$ Senia Pašeta (2013) Irish Nationalist Women, 1900-1918 (Cambridge, 2013), pp. 84-86.

${ }^{2}$ Irish Citizen (IC) 22 August, 1914.

${ }^{3}$ Ibid.

${ }^{4}$ Ibid.

${ }^{5}$ Ibid, 5 December, 1914

${ }^{6}$ Ibid, 6 January, 1915.

${ }^{7}$ Irish Times (IT), 16 February, 1915.

${ }^{8}$ Ibid, 12 June, 1916.

${ }^{9}$ Rosemary Cullen Owens (2001) Louie Bennett (Cork: Cork University Press), p. 30.

${ }^{10} I C, 12$ September, 1914.

${ }^{11}$ Irish Independent, 8 May, 1914.

${ }^{12}$ IC, 12 December, 1914.

${ }^{13}$ Ibid, 27 March, 1915.

${ }^{14}$ Ibid, 16 May, 1915, SSP, NLI, MS 22,674.

${ }^{15}$ Louie Bennett to FSS, 18 January, 1915, Sheehy Skeffington Papers (SSP), National Library of Ireland (NLI), MS 22,265.

${ }^{16}$ Elizabeth Browning to Francis Sheehy Skeffington (FSS), 17 August, 1914, SSP, NLI, MS 21,262.

${ }^{17}$ IC, 31 October, 1914.
} 
${ }^{18}$ Ibid, 7 November, 1914.

${ }^{19}$ H S Chenevix to FSS, 18 January, 1915, SSP, NLI, MS 22,259(iii), and FSS to Margaret

McCoubrey, 5 February, 1915, SSP, NLI, MS 22,259(iii).

${ }^{20}$ Dora Mellone to FSS, 6 December, 1915, SSP, NLI, MS 22,259(iii).

${ }^{21}$ IC, 12 September, 1912, and 22 August, 1914.

${ }^{22}$ Ibid, 12 September, 1912.

${ }^{23}$ Report of the Executive Committee of the Irish Women's Suffrage and Local Government Association for 1917 (Dublin, 1918), pp. 4-5.

${ }^{24}$ IT, 15 September, 1915.

${ }^{25}$ Edith Somerville to HSS, 5 March, 1915, SSP, NLI, MS 33,604(8).

${ }^{26}$ Church League for Women's Suffrage, November 1914, no. 35, p. 202.

${ }^{27}$ Theresa Londonderry, The Women's Legion, 1914, Londonderry Papers, Public Record Office of Northern Ireland (PRONI) D3099/14/1.

${ }^{28}$ The International Woman Suffrage News, 1 August, 1917, vol. II, p. 166.

${ }^{29}$ The Church League of Women's Suffrage, March, 1914, no. 27.p. 58.

${ }^{30}$ Mary Gwynn to HSS, 4 June, 1915, SSP, NLI, MS 33,604(9).

${ }^{31}$ Lady of the House, 14 August, 1915, p. 18.

${ }^{32}$ Ibid, 15 May, 1917, p. 22.

${ }^{33}$ Church League for Women Suffrage, November, 1914, no. 35, pp. 191-192.

${ }^{34}$ Violet Crichton to HSS, 1915, SSP, NLI, MS 33,604(9).

${ }^{35}$ Memoranda of Interviews, Sir Matthew Nathan Papers, Vol. III, MS Nathan 469, 28 January, 1916, Bodleian Library.

${ }^{36}$ Helena Chenevix to HSS, 1915, Sheehy Skeffington papers, NLI, MS 33,604 (13).

${ }^{37}$ IT, 19 April, 1916.

${ }^{38}$ IC, 14 November, 1914. At least 17 societies were represented on the Joint Committee: Freeman's Journal (FJ), 4 January, 1915.

${ }^{39}$ FJ, 26 February, 1910, p. 8.

${ }^{40}$ For further information about this See: Senia Pašeta, "Waging War on the Streets": The Irish Women Patrol, 1914-22', Irish Historical Studies, January, 2015, pp. 250-70.

${ }^{41}$ IT, 28 October, 1916.

${ }^{42}$ Theresa Moriarty, 'Work, Warfare and Wages: Industrial Controls and Irish Trade Unionism in the First World War', in Adrian Gregory and Senia Pašeta, Ireland and the Great War: A War to United us All (Manchester, 2002), p. 75.

${ }^{43}$ IT, 2 June, 1917.

${ }^{44}$ Irish Central Bureau for the Employment of Women First Annual Report (Dublin 1904), p. 4.

${ }^{45}$ Ibid, Thirteenth Annual Report, Dublin, 1916, no page numbers.

${ }^{46} I T, 17$ December, 1915.

${ }^{47}$ IC, 3 December, 1914, p. 230

${ }^{48}$ Memoranda of Interviews, Sir Matthew Nathan Papers, Vol. II, MS Nathan 468, 3 June, 1915, Bodleian Library.

${ }^{49}$ Annual Report of the Local Government Board for Ireland, 1915, British Parliamentary Papers (BPP), [Cd. 8016], p. 377

${ }^{50}$ Ibid, 1916, [Cd. 8365], pp. 216-217, 1917, [Cd. 8765], p. 280-81; 1918, [Cmd. 65], pp. 22-24.

${ }^{51}$ Ibid, 1915, [Cd. 8016], p. xxxi.

${ }^{52}$ Ibid, p. 63

${ }^{53}$ John Grindley to Principal Forth of the Municipal Technical Institute Belfast, 2 February, 1915, PRONI, BCT/8/5/3/4 
${ }^{54} I T, 25$ October, 1915

${ }^{55}$ David Fitzpatrick, 'Strikes in Ireland, 1914-21', Saothar, vol. 6, 1980, pp. 26-39.

${ }^{56}$ Moriarty, 'Work, Warfare and Wages', pp. 75-6.

${ }^{57}$ Fitzpatrick, 'Strikes' p. 27.

${ }^{58}$ Ibid.

${ }^{59}$ Board of Trade Labour Gazette, vol. XXII, no. 12, 1914, p. 459; vol. XXV, no. 12, 1917, p. 457.

${ }^{60}$ The price of bread had doubled by the end of 1917 in most of the UK: Board of Trade Labour

Gazette, Vol. XXII, no. 12, 1914, p. 452 and Vol. XXV, no. 6, 1917, p. 213.

${ }^{61}$ The Woman Worker, December, 1916, p. 7.

${ }^{62}$ Annual Report of the Local Government Board for Ireland, 1917, [Cd. 8765], p. 278.

${ }^{63}$ IT, 22 September, 1917.

${ }^{64}$ Irish Independent, 19 September, 1917.

${ }^{65}$ Annual Report of the Local Government Board for Ireland, 1918, BPP, [Cmd. 65], p. 21; Annual Report of the Local Government Board for Ireland, 1915, [Cd. 8016], p. 378.

${ }^{66}$ IT, 5 April, 1917.

${ }^{67}$ Padraig Yeates A City in Wartime: Dublin, 1914-18 (Dublin, 2012), p. 181.

${ }^{68}$ Mary Colum to Mabel Fitzgerald, 13 August, 1914, Desmond and Mabel Fitzgerald Papers,

University College Dublin Archives (UCDA), P80/1547 (1).

${ }^{69}$ Sinn Fein, 15 August, 1914..

${ }^{70}$ Ministry of Reconstruction. Report of the Women's Employment Committee, 1918, BPP, [Cd. 9239], p. 94.

${ }^{71}$ Workers' Republic, 18 December, 1918.

72 Tom Burke 'The Other Women of 1916' in History Ireland, September/October, 2006, vol. 14, no. 5 , p. 8.

${ }^{73}$ Daily Express, 22 April, 1914.

${ }^{74}$ Ibid, 25 April, 1914 and Burke, 'Other Women', p. 9.

${ }^{75}$ Annual General Report of the DATI, BPP, Cd. 8299, 1914-15, p. 86

${ }^{76}$ IT, 11 August, 1914; Lord and Lady Aberdeen We Twa: reminiscences of Lord and Lady Aberdeen, vol. II (London: Collins, 1925), pp. 229-30 and Eileen Riley, 'Women and Voluntary War Work', in Gregory and Pašeta, Ireland and the Great War, p. 48.

${ }^{77}$ Barry O'Delany, 'Cumann na mBan: The Women's Auxiliary of the Irish Army' in William G. Fitz-Gerald (ed.), The Voice of Ireland: A Survey of the Race and National From all Angles by the Foremost Leaders at Home and Abroad (Dublin and London, 1924), p. 162.

${ }^{78}$ Cumann na mBan Leabhar na mBan (Dublin, 1919), p. 2, and Mary Colum and Louise Gavan Duffy to Nannie O'Rahilly, 12 August, 1914, O'Rahilly Papers, UCDA, P102/484

${ }^{79}$ The Irish Volunteer, 26 September, 1914.

${ }^{80}$ The Royal Commission on the Rebellion in Ireland; Minutes of Evidence and Appendix of Documents, 1916, BPP, [Cd. 8311], p. 197.

${ }^{81}$ Leabhar na mBan, p. 5.

${ }^{82}$ FJ, 11 May, 1914.

${ }^{83}$ Pašeta, Nationalist Women, pp. 152-153.

${ }^{84}$ Burke, 'Other Women', p. 8.

${ }^{85}$ IT, 29 September, 1917.

${ }^{86}$ The Irish Women's Association, cards and information letters, O'Hara Papers, NLI, MS 36,446/4.

${ }^{87}$ Ulster Women's Gift Fund to Dowager Marchioness of Londonderry, 4 November, 1916, Londonderry Papers, PRONI, D2846/1/9/8. 
${ }^{88}$ Ulster Women's Gift Fund to the Secretary of the Central Prisoners of War Committee, London, 3 November, 1915, Londonderry Papers, PRONI, D28461/9/6.

${ }^{89}$ Dublin Express, 26 September, 1914

${ }^{90}$ Czira, Sydney The Years Flew By: The Recollections of Madame Sydney Czira, (Dublin, 1974), p. 51.

${ }^{91}$ The Times, 4 October, 1916.

${ }^{92}$ Northern Whig, 10 April, 1918.

${ }^{93}$ Ibid, 11 April, 1918.

${ }^{94}$ Enid Starkie A Lady's Child (London, 1941), pp. 199-200.

${ }^{95}$ IT, 17 January, 1918.

${ }^{96}$ Rosemary Cullen Owens Smashing Times: A History of the Irish Women's Suffrage Movement, 1889-1922 (Dublin, 1984), pp. 120-21.

${ }^{97}$ Irish Independent, 22 April, 1918.

${ }^{98}$ Pašeta, Nationalist Women, pp. 241-245

${ }^{99}$ Irish Independent, 1 June, 1918.

${ }^{100}$ FJ, 10 June, 1918.

${ }^{101}$ Seventy Years Young: Memoirs of Elizabeth, Countess of Fingall told to Pamela Hinkson, (Dublin, Collins, 1990), pp. 362-363.

${ }^{102}$ Susan Grayzel Women and the First World War (Harlow, 2002), pp. 3-6. I am very grateful to Susan Grayzel for her advice about this article and for the ideas she shared with me in Oxford. ${ }^{103}$ Lady of the House, 15 March, 1918, p. 5. 